\section{Hexose-phosphate as an Inter- mediate in the Assimilation of Methanol by Candida sp}

\section{Takaaki FumI and Kenzo TonomurA \\ Fermentation Research Institute, Inage, Chiba}

Received October 3, 1972

A number of studies on the assimilation of methane, methanol and formate by bacteria have so far revealed the following pathway; the ribulose diphosphate cycle, ${ }^{11}$ the glycine-serine pathway ${ }^{2,3}$ and the allulose phosphate pathway. However, the assimilative pathway of methanol in yeast has not been reported. The previous paper $^{51}$ has shown that Candida N-16 capable of growing on methanol can oxidize methanol, formaldehyde and formate to carbon dioxide. In the present paper it is reported that most of the radioactivity of ${ }^{14} \mathrm{C}$-methanol fixed by the yeast at the earliest time of incubation appeared in hexose-phosphate, presumably fructose or its-related compound.

The yeast was grown in a medium containing $1 \%(\mathrm{w} / \mathrm{v})$ methanol at $30^{\circ} \mathrm{C}$ as described previously. ${ }^{5 \prime}$ Cells in a logarithmic growth phase were harvested by centrifugation, washed twice with $10 \mathrm{~mm}$ phosphate

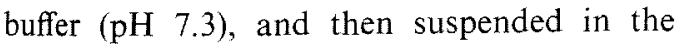
same buffer. The incorporation of ${ }^{14} \mathrm{C}$ methanol was carried out in a $50 \mathrm{ml}$ Erlemmyer flask containing $10 \mathrm{ml}$ of a reaction mixture. The reaction mixture consisted of $19 \mathrm{mg}$ (dry wt.) of cells, ${ }^{14} \mathrm{C}$-methanol (100 $\mu \mathrm{Ci}, 20 \mu$ moles) and $40 \mu$ moles of phosphate buffer ( $\mathrm{pH}$ 7.3). At time intervals $1 \mathrm{ml}$ of the mixture was transferred to $4 \mathrm{ml}$ of hot ethanol, boiled for $20 \mathrm{~min}$ and then centrifuged. The resultant precipitates were extracted with $5 \mathrm{ml}$ of $20 \%$ ethanol and centrifuged. The combined supernatant was evaporated to dryness under a reduced pressure at $45^{\circ} \mathrm{C}$. The residue was dissolved in $100 \mu \mathrm{l}$ of $20 \%$ ethanol, $50 \mu \mathrm{l}$ of which was applied on filter paper (Toyo No. 50) for two-dimentional and descending paper chromatography using the following solvents: ${ }^{0}$ phenol-water $(100: 40, \mathrm{v} / \mathrm{v})$ and $n$-butanolpropionic acid-water (142:71:100, v/v). After chromatography the paper was exposed to X-ray film (Sakura X-ray film; non-screen type $\mathrm{N}$ ) to prepare radioautogram. Radioactive spots were cut out from chromatogram and the radioactivity was measured by a liquid scintillation spectrometer (Packard 'Tricab' model 3320). A scintillation mixture contained $4 \%$ naphthalene, $0.4 \% 2,5$-diphenyloxazole and $0.01 \%$ 1,4-bis-2-(5-phenyloxazolyl)-benzene in dioxane-cellosolve-toluene $(3: 3: 10, v / v)$. The radioactivity of a phosphorylated compound was measured after the compound was eluted from chromatogram, hydrolyzed by phosphatase and subjected to two-dimentional paper chromatography using the following solvents: ${ }^{7}$ phenol-water $(5: 1$, $\mathrm{v} / \mathrm{v})$ and $n$-butanol-pyridine-water $(6: 4: 3$, $\mathrm{v} / \mathrm{v})$. For dephosphorylation the compound was incubated with $100 \mu \mathrm{g}$ of acid phosphatase (wheat germ, Seikagaku Kogyo Co.) in $100 \mu 1$ of $2 \mathrm{~mm}$ acetate buffer (pH 5.0 ) at $30^{\circ} \mathrm{C}$ for $12 \mathrm{hr}$. The identification of a radioactive compound was carried out by cochromatography with each authentic sample. The two-dimentional paper chromatography of sugar was carried out by the following solvents: $:^{8}$ phenol $-90 \%(\mathrm{w} / \mathrm{v})$ formic acid-water (500: 13:167, w/v/v) and $n$-butanol-propionic acid-water $(47: 22: 31, v / v)$. For the paper chromatography of amino acid, ethanol-water $(7: 3, v / v)$ was used as solvent, and for carboxylic acid $n$-butanol-acetic acid-water (4:1:2, $\mathrm{v} / \mathrm{v}$ ). The radioactive spot was revealed by radioautography and the authentic compound was detected by spraying with the following reagent: for ketose $^{9} 0.2 \%$ naphthoresorcinol in ethanol-phosphoric acid $(10: 1, v / v)$, for aldose ${ }^{10)}$ a reagent containing $2 \mathrm{~g}$ of diphenyl amine, $2 \mathrm{ml}$ of aniline and $10 \mathrm{ml}$ of $80 \%$ phosphoric acid in $100 \mathrm{ml}$ of acetone, for amino acid $0.02 \%$ ninhydrine in butanol and for carboxylic acid $0.1 \%$ bromocresol green (pH 5.0) in ethanol.

The radioactivity of ${ }^{14} \mathrm{C}$-methanol rapidly 


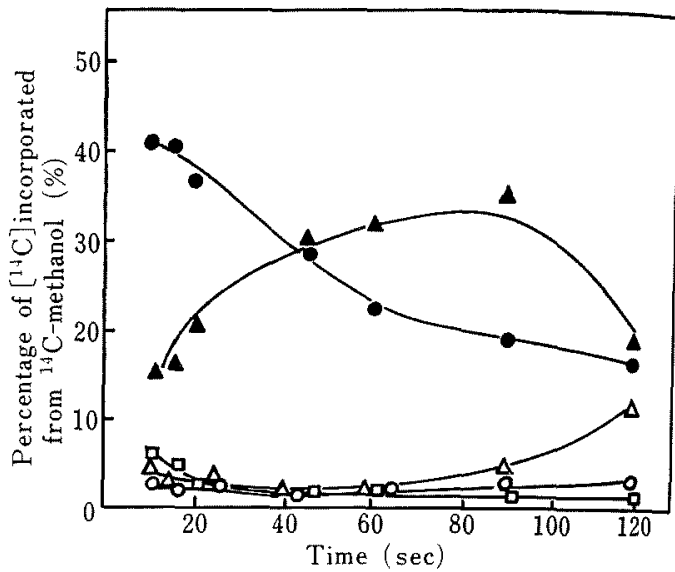

FIG. 1. Time Course of the Percentage Distribution of Radioactivity Incorporated from ${ }^{14} \mathrm{C}$-Methanol into Fructose Phosphate (๑), Glucose phosphate $(\Delta)$, Serine + Glycine $(O)$, Alanine $(\Delta)$ and Malate (口).

appeared in a number of substances during the incubation of the yeast. The radioactivity distributed for the first $2 \mathrm{~min}$ incubation is shown in Table I. Over $70 \%$ of the radioactivity incorporated for the first $10 \mathrm{sec}$ was found in phosphorylated compounds, and about $90 \%$ of the radioactivity of those compounds was found in hexose-phosphate. The variation with time of the percentage distribution of the radioactivity incorporated from ${ }^{14} \mathrm{C}$-methanol into fructose phosphate, glucose phosphate, serine+glycine, malate and alanine is shown in Fig. 1. The variation curve of fructose phosphate showed a negative slope against a time. The variation of malate also showed a negative slope, although the total radioactivity incorporated into malate was relatively small. On the other hand, the variation of glucose phosphate, alanine and serine + glycine showed positive slope, respectively. These results suggest that fructose phosphate may be a primary intermediate in the assimilation of methanol by Candida sp.

\section{REFERENCES}

1) J. R. Quayle and D. B. Keech, Biochem. J., 72, 631 (1959).

2) T. Kaneda and J. M. Roxburgh, Biochim. Biophys. Acta, 33, 106 (1959). 
3) P. J. Large and J. R. Quayle, Biochem. J., 87, 386 (1963).

4) M. B. Kemp and J. R. Quayle, ibid., 102, 94 (1967).

5) T. Fujii and K. Tonomura, Agr. Biol. Chem., 36, 2297 (1972).

6) N. Ogasawara and S. Miyachi, Plant and Cell Physiol., 11, 1 (1970).
7) A. Jeanes, C.S. Wise and R. J. Dimler, Anal. Chem., 23, 415 (1951),

8) M. B. Kemp and J. R. Quayle, Biochem. J., 99, 41 (1966).

9) V. Prey, H. Berbalk and M. Kausz, Mikrochim. Acta, 1961, 968.

10) R. W. Bailey and E. J. Bourne, J. Chromatog., 4, 206 (1960). 